\title{
STUDENTS' PERCEPTIONS OF LEARNING, USING INTERACTIVE NOTES
}

\author{
E. Papageorgiou \\ School of Accountancy \\ University of the Witwatersrand \\ Johannesburg, South Africa \\ e-mail: Elmarie.Papageorgiou@wits.ac.za / https://orcid.org/0000-0001-9356-6123
}

\section{ABSTRACT}

Orientation: The main purpose of teaching should be to encourage and promote learning.

Purpose: To assist lecturers to gain additional information about how students learn, through the use of "interactive notes", as opposed to "comprehensive notes" that could affect their academic performance. Due to the lack of student engagement in large classes, the study investigated students' perceptions of learning in lectures to establish how students learn and whether they have learnt and/or acquired knowledge in lectures.

Research Problem: The research question was "what teaching aids/tools accounting students prefer in relation to their race, gender, language and/or academic performance on how students learn and/or acquire knowledge in lectures"?

Methodological approach: The research study was exploratory; $\mathrm{N}=382$ students participated in the study at a South African university. Standard multiple regression analysis was employed and statistical tests were conducted to determine the relationships between categorical variables to answer the research question.

Major findings: The findings provide a source for educators to introduce interactive learning in lectures. An increase in students' academic performance was noted with the inclusion of "interactive notes" in lectures. We also find that students learn better when they actively engage, participate and interact in lectures when taking notes.

Conclusion: The value of the study contributes to the knowledge of research in addressing firstyear students' learning perceptions in a more effective learning environment.

Keywords: Academic performance, accounting, students, interactive notes, learning, students, university

\section{INTRODUCTION}

"I hear and I forget. I see and I remember. I do and I understand. Confucius (551-479 BC)" (Johnson 2003). Accounting is a practical course that builds on theory, principles and concepts and is one of the main courses in producing accountants through higher education processes that are facing challenges in global accounting education (Albrecht and Sack 2000; Sikka et al. 2007). Scott, Yeld, and Hendry $(2007,10)$ state that higher educational processes can be 
improved to meet students' appropriate "learning needs to allow them to reach their full potential". For the past six decades, but also more recently, empirical evidence has explored different learning preferences and highlighted active learning as a means of promoting student academic success (Apfelthaler et al. 2005; Dennehy 2014a; Dennehy 2014b; Malmquist and Collins 2017). Today, higher education faces the challenge to not only teach students in large classes with a curriculum that is overloaded and specific, but also having to "develop skills that will enable students to become versatile experts in their own fields and lifelong learners" (Asikainen and Gijbels 2017, 206).

Students learn differently in respect of which country they from, each country have their own governing body and in South Africa the Department of Higher Education (DOE) in conjunction with the South Africa Qualification Authority (SAQA) regulate means of delivery to students (Beyleveld, De Villiers, and Fraser 2019). These governing bodies however do not provide how lecturers must deliver their lectures and "is often left to the discretion of each higher education institution whether public or private when applying these strategies" (Beyleveld et al. 2019, 17). Accounting is a practical subject but students need to learn terminology, definitions and basic concepts before the practical element can be introduced (Hall, Ramsay, and Raven 2004) and therefore need guidance how to learn theory. Different learning tools and strategies were explored to teach Accounting, one of these teaching tools to consider was active learning in lectures.

Currently, in a new setting, attention has switched to identify possible teaching aids, learning tools and teaching strategies that could assist students to learn better in lectures using active learning, assisting them to pass and eventually graduate (Beyleveld et al. 2019). Dennehy (2014a, 2) developed various "research tools and conceptual frameworks in an attempt to define and measure potential learning differences". Biggs (1993) confirms that learning cannot be viewed in isolation but should be considered with other factors, such as students' prior experiences and knowledge, curriculum, assessments, teaching styles and perceptions of learning.

The motivation for the study originates from an increased interest in the use of teaching materials in lectures, and the continued demands for improving lectures to actively engage with students in large classes. In these classes, there is a general lack of engagement, difficulties attending to students individually and limited opportunity for active learning (Zhang 2005). Due to the lack of student engagement in large classes, the attention of this study was to focus on developing an active, creative and hopefully, a life-long learning culture in lectures to embed at an early stage of their studies. Furthermore, this article "seeks to support students in developing a better awareness and understanding of themselves as learners" and how they learn 
in lectures (Lucas and Meyer 2005, 177). Precourt and Gainor $(2019,100)$ confirmed that "students participating" and engaging in lectures "perform $25 \%$ better in exams" comparing to students who had a lower participation grate. The motivation for this study is further justified by the study by Stone $(2012,5)$ that concluded that the "flipped classroom" provides lecturers "the opportunity to walk around" in the classroom interacting with the students and listening to students' opinions and concerns. This article reports on a study of lectures offered to accounting students in their first year at a South African university to ascertain students' perceptions and their preferences for different teaching aids/tools and whether they have learnt in lectures and/or acquired knowledge. Therefore, the aims of the study are to investigate students' perceptions and opinions of how students learn in lectures, the level of student engagement in the context of accounting studies. Standard multiple regression analysis was employed and statistical tests were conducted to determine the relationships between categorical variables to answer the research questions. The research was guided by the following questions:

- What teaching aids/tools first year accounting students prefer in relation to their gender, race, language and/or academic performance?

- How do students learn and/or acquire knowledge in lectures?

The following objectives of the study address the aims of the study:

- To identify teaching aids/tools students prefer regarding to gender, race, language and/or academic performance;

- To explore how students learn and acquire knowledge in lectures, based on students' perceptions; and

- To determine the relationship between "interactive notes" and student performance.

While it is important to understand how students learn, it is also important to understand which teaching aids/tools they prefer. Fry, Ketteridge, and Marshall (2009) confirm that not everyone learns in the same way, since students with diverse backgrounds bring different expectations to learning. The main findings confirmed that students prefer the "use of interactive notes ..." as their preferred teaching aid/tools, and that the level of statistical significance indicates an association between the preferred teaching aid/tools and students' academic performance. The value of this research contributes to the knowledge of research in not only addressing accounting students' learning perceptions and acquiring knowledge in lectures, but also adds value to other practical and non-practical courses at universities. Furthermore, the contributions of the article offer a source for accounting lecturers who wish to introduce interactive learning 
in their course material to firstly, expose students to "interactive notes" in lectures which might influence students' academic performance and secondly, to evaluate the impact of the inclusion of "interactive notes" in the course material.

The balance of this article is discussed as follows; the literature review, followed by the research design, results and discussion, conclusion, limitations and recommendations for future research.

\section{LITERATURE REVIEW: TEACHING AND LEARNING IN PERSPECTIVE}

Students learn in different ways depending on their age, achievement levels, culture, intellectual capacity, and ability to process new information. "Teaching can be rewarding but it can also be frustrating when some students fail to grasp the course material" (Boyle and Dunn 1998, 213). According to Dunn and Dunn (1979), lecturers should investigate innovative strategies to assist students to demonstrate their acquisition of the knowledge in order to proceed to the next academic level. Dunn and Dunn (1979) state that students with similar characteristics tend to adopt a particular learning method, and lecturers confirmed that students who are taught through methods that complement their learning characteristics, are motivated to obtain better academic marks.

Biggs (1993) confirms that learning is not viewed in isolation but must be considered together with other factors as illustrated in Figure 1. This study has adapted the model of Biggs (1985) and Ramsden (1992), focusing on parts one, two and five.

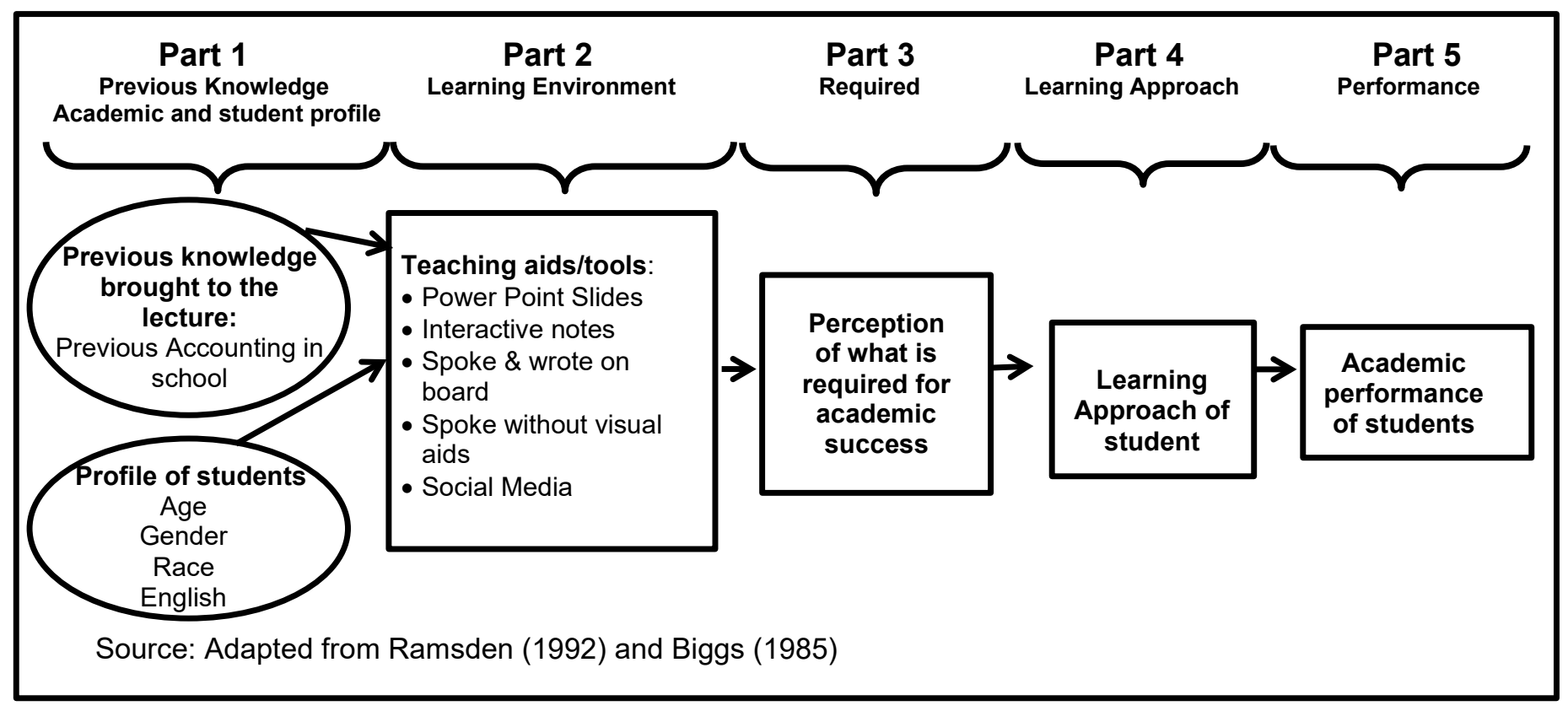

Figure 1: Teaching and learning in perspective model 
Figure 1 is analysed as follows: Part one, indicates previous knowledge brought to lectures and students' profile (age, gender, race and English as a home language (HL) or first additional language (FAL)). Part two, indicates the learning environment, which consists of five possible teaching aids/tools; part three indicates the perception of what is required for academic success for both student and teacher; part four indicates the learning approach of students; and finally, part five indicates the academic performance/outcome of students. Each part of the model contributes to the learning and teaching perspective, but it is important to emphasise that lecturers have no control over "Part one", "but do have full control over the learning environment" (Part two) (Biggs 1985; Booth, Luckett, and Mladenovic 1999, 280; Ramsden 1992).

Numerous studies have investigated learning styles and student approaches to learning in various disciplines, but the studies of Mashishi and Rabin (2000) and Visser, McChlery, and Vreken (2006) refer to studies in accounting. Mashishi and Rabin (2000,1) studied "the approaches to learning, engagement within the learning context and conceptions of learning", while Visser et al. $(2006,97)$ studied "teaching styles". This study builds on the models of Biggs (1985) and Ramsden (1992), by adapting the learning environment (Part two) and reflects on the findings as a result of this change.

Duff $(2007,410)$ confirms "that there are a range of factors which affect students' academic performance" in higher education institutions, especially in their first year of study. Prior studies (Biggs 1987; Raaheim, Wankowski, and Radford 1991; Tait and Entwistle 1996; Papageorgiou 2017) indicate that factors such as gender, age and previous academic performance are significant predictors of academic performance. This article investigates lectures offered to accounting students at a university in South Africa "where there are extremely large classes, cultural differences, diverse ranges of prior knowledge" and differences in the way students learn (Marburger 2010; Müller, Prinsloo, and Du Plessis 2007; Scott et al. 2007; Papageorgiou and Callaghan 2018, 459; Steenkamp, Baard, and Frick 2009; Winebrenner 2007). This study is considered particularly important by investigating the following criteria of students' profile and prior knowledge.

Firstly, the studies of Rowlands (1988) and Van Rensburg, Penn, and Haiden (1998) conclude that students with prior knowledge of accounting perform better in the early stages of accounting than students with no prior knowledge, while Bergin (2001) found no relation. Secondly, in earlier accounting studies, "age has been ignored as a predictor of academic performance" (Duff 2007, 413), while other studies concluded that younger students perform better than more mature students (Dockweiler and Willis 1984; Koh and Koh 1999). Bartlett, Peel, and Pendlebury (1993) state that age is not associated with students' academic 
performance. Thirdly, mixed findings reported on the relationship between gender and academic performance. Chansarkar and Michaeloudis $(2001,103)$ conclude that the "performance of students is not affected by factors such as age and gender", while Gammie, Paver, Gammie, and Duncan (2010) have found that females outperformed males in the accounting module at first-year level. Fourthly, Apfelthaler et al. $(2005,247)$ confirm that "with diverse classrooms also comes diversity in learning behaviour of students which poses challenges for students, faculty, and administrators in higher education". Furthermore, De Vita $(2010,165)$ states that the reasons for the mismatch between lecturers' methods and students' learning styles are as a result of a diverse student group who has "different backgrounds and different approaches to learning". In order to understand how students learn, Jacobs (2000) suggests that it is important to recognise these diverse student backgrounds as some students need more assistance with the transition from high school to university, where they are required to adapt to deeper modes of thinking and understanding. And finally, Wong and Chia (1996) and Gul and Fong (1993) indicate that high school certificate level grades in English are a significant predictor of student performance: while De Vita $(2010,165)$ states "students for whom English is not their first language or culture may be culturally predisposed to learn in ways that may not always be compatible with the 'local' and 'common' method of instruction". In this context, Scrivener (2005) states that the lecturer's main role is to "help learning to happen" by encouraging students to participate, talk, and interact. Marton and Booth (1997) confirm that the only route to learning is the learner's own experiences, such as, what makes them learn, what do they learn and do they learn. After years of research into learning and especially accounting education, there is no easy answer to questions "How do we learn?" and "How do lecturers teach and bring about the best learning in students?" (Fry et al. 2009; Pratt 2005). Sharma (1997, 125) confirmed that "students' perceptions of the learning context influence their learning approaches" and may produce better quality accounting students.

Student learning indicates that both students' tendencies to learning and the "learning environment" affect the "learning approach" and eventually, academic performance/outcome (Biggs 1993; Booth et al. 1999, 279). Booth et al. (1999) further explain that lecturers are not in control of students' tendencies to learning but have full control over the learning environment. Prior studies concluded that "active-learning style" in the flipped approach can increase student learning over traditional non-active learning approaches (Jensen, Krummer, and Goby 2015, 1; Love et al. 2014; Strayer 2012; Bishop and Verleger 2013). The "flipped classroom" is to flip the common instructional traditional approach to interactive lessons (Rotellar and Cain 2016, 1; Koo et al. 2016). Roach $(2014,74)$ states that flipped classrooms are leading to "a new era of active and creative thinkers" and provide lecturers the opportunity 
to create learning experiences and to encourage engaging students in enriching activities and interactive experiences in lectures (Bristol 2014; Kim 2017). Pierce, Fox, and Dunn (2012) confirmed that the flipped classroom has gained acknowledgment to promote a studentcentered approach, which is active learning.

\section{RESEARCH DESIGN}

The research study was exploratory, employing a quantitative research approach. The target population in the study included 538 registered accounting students at a university in South African. This course is compulsory for students enrolled for the General and Accounting Bachelor of Commerce (BCom) degrees and students need to attend 4-5 lecture periods and three tutorial periods of 45 minutes each per week. Tutorials are used to develop students' skills: the application of accounting principles and concepts, the development of a sound method in solving problems (Mashishi and Rabin 2000), ability to interact and participate. An interactive environment between students and tutors are created in tutorial classes to grow accounting students' confidence in handling and solving problems (Mashishi and Rabin 2000) and creating an informal approach to effective learning. However, students sometimes only rely on the tutorial system to interact and engage in understanding of different terminologies, principles and concepts taught in lectures. The Accounting I course material is distributed at the beginning of each semester. Table 1 illustrates the two types of course material used in the Accounting I e: comprehensive notes and interactive notes.

Table 1: Comprehensive notes versus Interactive notes

\begin{tabular}{|c|c|c|}
\hline $\begin{array}{c}\text { Students' } \\
\text { involvement }\end{array}$ & Comprehensive Notes & Interactive Notes \\
\hline $\begin{array}{l}\text { Before } \\
\text { lectures }\end{array}$ & $\begin{array}{l}\text { Students receive source material on } \\
\text { some topics at the beginning of each } \\
\text { semester that consists of } \\
\text { comprehensive notes (whereas other } \\
\text { topics consist of interactive notes), } \\
\text { meaning that these notes are } \\
\text { complete. } \\
\text { Students have the opportunity to pre- } \\
\text { read their comprehensive notes to } \\
\text { engage in lectures. }\end{array}$ & $\begin{array}{l}\text { Students receive course material on some topics at } \\
\text { the beginning of each semester that consists of } \\
\text { interactive notes (whereas other topics consist of } \\
\text { comprehensive notes), meaning that notes are } \\
\text { partially completed or not at all to provide students } \\
\text { the opportunity to complete the notes in lectures by } \\
\text { interacting and engaging in lectures. } \\
\text { Students have the opportunity to pre-read their } \\
\text { interactive notes to engage in lectures and to } \\
\text { possibly complete the interactive notes before } \\
\text { lectures. Therefore, learning may transpire before } \\
\text { lectures as students engage with the interactive } \\
\text { notes as part of the learning process. }\end{array}$ \\
\hline $\begin{array}{l}\text { During } \\
\text { lectures }\end{array}$ & $\begin{array}{l}\text { Students listen to the lecturer and } \\
\text { may actively engage to understand } \\
\text { accounting principles and concepts. }\end{array}$ & $\begin{array}{l}\text { Students engage and interact in lectures by } \\
\text { completing the notes in lectures in using this flipped } \\
\text { format oppose to the comprehensive notes. The } \\
\text { biggest advantage for lecturers in using this format } \\
\text { is to use the lecture time to possible force students } \\
\text { to apply their new conceptual understanding of the } \\
\text { topic taught in the lecture by engaging in lectures, } \\
\text { therefore, the process of learning transpires in } \\
\text { lectures. Students are assessed in accounting tests }\end{array}$ \\
\hline
\end{tabular}




\begin{tabular}{|l|l|l|}
\hline $\begin{array}{c}\text { Students' } \\
\text { involvement }\end{array}$ & \multicolumn{1}{|c|}{ Comprehensive Notes } & \multicolumn{1}{c|}{ Interactive Notes } \\
\hline & \multicolumn{1}{|c|}{$\begin{array}{l}\text { and exam using this approach of students' } \\
\text { understanding the concepts learnt in lectures. }\end{array}$} \\
\hline After lectures & $\begin{array}{l}\text { Learning may take place after } \\
\text { lectures to allow students to explore } \\
\text { the content of 5he comprehensive } \\
\text { notes and construct their own } \\
\text { understanding of concepts taught in } \\
\text { lectures. }\end{array}$ & $\begin{array}{l}\text { Students may revise accounting concepts and } \\
\text { principles learn it in lectures and may delve more } \\
\text { deeply into additional examples to strengthen the } \\
\text { framework of accounting concepts and principles. } \\
\text { Students may solve higher-order problems using of } \\
\text { what they learnt in lectures. }\end{array}$ \\
\hline $\begin{array}{l}\text { Before } \\
\text { tests/exams }\end{array}$ & $\begin{array}{l}\text { Students may include additional notes } \\
\text { to the comprehensive notes to fully } \\
\text { understand accounting concepts and } \\
\text { principles learnt in lectures and then } \\
\text { revise. }\end{array}$ & $\begin{array}{l}\text { Students are hopefully more prepared for } \\
\text { tests/exam being exposed to interactive notes since } \\
\text { students learnt in lectures and took responsibility of } \\
\text { their own learning. Students link their own } \\
\text { interactive notes to facilitate concept building. }\end{array}$ \\
\hline
\end{tabular}

It was therefore decided to enhance the learning environment by focusing on lectures to enable students to interact, participate and engage in lectures. "Students learn better when they actively" engage and participate in lectures (Precourt and Gainor 2019, 101; Kember and Gow 1994). Precourt and Gainor $(2019,101)$ state that "the definition of active participation ranges from mere listening and taking notes to offering unsolicited responses and contributions to class discussions, and at the highest level, might include actions beyond verbal communication including writing insightful and evaluative responses and papers". Therefore, for students to interact, participate and engage in lectures, "Interactive notes" (see Table 1), as part of the controllable learning environment (Part two), were added to the traditional list of teaching aids/tools to investigate whether the inclusion would influence students' academic performance. Interactive notes were included in students' course material, as opposed to "comprehensive notes" (see Table 1) to encourage participation and engagement in lectures. Interactive notes are notes that are partially completed as opposed to fully completed notes (comprehensive notes) thus enabling students to complete these notes in lectures by engaging and taking part in lectures. By providing students with comprehensive notes, this could influence students not to engage and participate in lectures.

The purpose of this study was also to assist lecturers to gather additional information about how students learn, through the use of "interactive notes", as opposed to "comprehensive notes" that could affect their academic performance. The interactive notes could encourage students to complete the notes during lectures; in this way, listening, interactive learning, engaging, and participation were incorporated into the lectures. The most important claim of this study, is how interactive notes enable students to participate in lectures, and that the use of interactive notes could address the need for various activities in large lectures, such as, listening, reading, writing, doing, thinking .... Students need to attend lectures to complete the interactive notes as opposed to comprehensive notes that are complete and students may be absent and not attending lectures. The completing of the notes in lectures enabled lecturers to engage with students and 
create a learning environment, as suggested by Hoyle (2006) and Bain (2004). Figure 2 illustrates the process of learning in lectures by using interactive notes to underpin the theoretical framework of prior studies as confirmed by Biggs's (2003) argument that learning is happening by student's "learning activities", whereby they learn through "filling in the answers" on notes.

\begin{tabular}{|c|c|}
\hline $\mathbf{L}$ & $\begin{array}{l}\text { Listen: Students attending lectures need to } \\
\text { listen to lecturers to enable them to engage, } \\
\text { participate and interact (Jensen et al. 2015; } \\
\text { Precourt \& Gainor 2019). }\end{array}$ \\
\hline $\mathbf{E}$ & $\begin{array}{l}\text { Engage: Students need to engage in } \\
\text { lectures to enable them to engage in the } \\
\text { process of learning (Bristol 2014). Students } \\
\text { "are willing to engage in active learning to } \\
\text { become critical thinkers..." Precourt \& Gainor } \\
2019,114 \text { ). }\end{array}$ \\
\hline A & $\begin{array}{l}\text { Assess: Assessing and evaluating students } \\
\text { are the outcomes of students' learning } \\
\text { process in testing students' understanding of } \\
\text { accounting concepts learnt in lectures. } \\
\text { (Jensen et al. 2015). }\end{array}$ \\
\hline $\mathbf{R}$ & $\begin{array}{l}\text { Revise by reading: Revising course material } \\
\text { after lectures could support the learning } \\
\text { process and eventually the academic } \\
\text { outcome. }\end{array}$ \\
\hline $\mathbf{N}$ & $\begin{array}{l}\text { Notes, interactive: Ability to use lecture time } \\
\text { in a hands-on manner in engaging with the } \\
\text { course material instead of passively just } \\
\text { listening (Roach 2014). The scarcest } \\
\text { learning resource is time (Tucker 2012) } \\
\text { "Taking notes... at the highest level..." } \\
\text { Precourt \& Gainor 2019, 101). }\end{array}$ \\
\hline
\end{tabular}

Figure 2: The process of learning in lectures using interactive notes 


\section{Measures}

Two measures were used in the study: firstly, a self-developed questionnaire to measure the perceptions of students of different teaching aids/tools used in Accounting I lectures and secondly, the students' academic performance expressed as the marks obtained in tests. The questionnaire consisted of closed questions, as well as open-ended questions, which added value to the study since the students had the opportunity to raise their opinions about different teaching aids/tools. The participants were briefed by the researcher in the lecture and invited to complete a questionnaire in their tutorial class, the questionnaire was voluntary and students were ensured that their participation would not affect their academic performance. The questionnaire used in this study drew on existing literature (Dennehy 2014a; Duff 2007; Dunn and Dunn 1979) to provide a theoretical basis and thought process for determining students' perceptions of different teaching aids/tools. The questionnaire built on the approach used in the "Study Process Questionnaire (SPQ)" (Dennehy 2014a; Biggs 1987; Biggs, Kember, and Leung 2001; Kember et al. 1995), which assesses the extent to which students at a university endorse different approaches to learning, motives and strategies. Students indicated which of the five teaching aids/tools used in the Accounting I course they preferred and expressed their opinions and perceptions (open-ended questions) toward which teaching aid/tool could contribute to learning in lectures. The open-ended questions assisted lecturers to gain valuable information about insights into students' learning modes, whether students have learnt in the lectures. The academic performance was measured on a 1-100 per cent scale with a mark of 50 per cent or above as a pass with a mean of 61.00 and a SD of 12.849. The April and June Accounting tests' marks were combined as a year-to-date mark as a measure of the students' academic performance.

\section{Data collection}

Firstly, April and June accounting tests' marks, data such as gender and race, and whether English was their HL or FAL were collected from the institution's database; 538 students were recorded. Secondly, data were collected the end of the second semester from the questionnaire that was administered in the tutorial classes. Thereafter the data were combined on a spreadsheet.

\section{Analysis}

The "SPSS Statistical Package" (V26) was used to analyse the data for basic frequencies and descriptive statistics to describe the sample and the "Chi-square test" was conducted to determine the relationships between variables. A correlation of different variables and teaching 
tools were carried out to identify any significant associations. Furthermore, a multiple regression analysis was conducted of students' academic performance on the different teaching tools to investigate if any further correlations existed. The Ethics Committee of the academic institution issued an Ethics Clearance Certificate, validating and approving the empirical study.

\section{RESULTS AND DISCUSSIONS}

Tables 2 to 5 and Figure 3 illustrate the results which addressed the research objectives of the study. Descriptive statistics are shown in Table 2: 382 first-year Accounting I students participated in the computerised questionnaire, a response rate of 71.0 per cent, of which 58.1 per cent were African students and 51.8 per cent were male students. With regard to language, 74.9 per cent of the respondents confirmed that English was their HL and 25.1 per cent of the respondents had English as FAL. The data received did not indicate whether English was the first, second or third additional language. Most of the students who responded to the questionnaire registered for the Accounting degree majoring in Accounting.

Table 2: Accounting I respondents' demographics

\begin{tabular}{|l|c|c|}
\hline \multicolumn{1}{|c|}{ Race } & Frequency & $\%$ \\
\hline African & & \\
\hline Indian & 222 & 58.1 \\
\hline White & 89 & 23.3 \\
\hline Other & 61 & 16.0 \\
\hline Total Gender & 10 & 2.6 \\
\hline \multicolumn{1}{|c|}{ English Language } & 382 & 100.0 \\
\hline Male & 198 & 51.8 \\
\hline Female & 184 & 48.2 \\
\hline Total & 382 & 100.0 \\
\hline \multicolumn{1}{|c|}{ English as Home language (HL) } & 286 & 74.9 \\
\hline English as First additional language (FAL) & 96 & 25.1 \\
\hline Total (N = 382) & 382 & 100.0 \\
\hline
\end{tabular}

Different teaching aids/tools, or ways of delivery, are aimed at how students engage with lecture material, using different senses such as listening; listening and doing; listening, doing, thinking in acquiring knowledge and/or to learn in lectures. Valuable information as to how students learn best was gained by asking students the following question: "Which of the following teaching aids/tools did you find useful when learning different Accounting I topics in lectures?" Where the Lecturers:

- $\quad$ use PowerPoint Slides only; 
- use interactive notes where you had to fill in the answers to short questions and then worked through detailed questions;

- $\quad$ spoke and wrote on the board and overhead slide;

- $\quad$ spoke without any visual aids; and

- $\quad$ used Social Media to explain the topic of a lecture.

Students were exposed to all the different teaching aids/tools and had had experience with all the tools before students completed the survey. Two of the four lecturers who lectured on the course used "interactive notes" while the other lecturers used a combination of the remaining teaching aids/tools.

As per Table 3, the findings confirmed that the teaching aid/tool, "use of interactive notes where you had to fill in the answers to short questions and then worked through detailed questions", scored the highest 66.8 per cent, followed by "spoke and wrote on the board and overhead", which scored 57.1 per cent. "Spoke without any visual aids" scored the lowest, 8.4 per cent. The "use of interactive notes ..." as the preferred teaching aid/tool when learning accounting is confirmed in the studies of Bain (2004), Hoyle (2006) and Morton (2009), which indicate that engaging with students in an interactive and creative learning environment may achieve active learning. The results also concur with Biggs's (2003) argument that learning is happening by student's "learning activities", such as learning by "filling in the answers" on the notes. Venter $(2019,247)$ stated that while "formal and informal learning networks exist independently of each other they intersect when students engage with one another to further their studies".

Table 3: Students' perceptions in choice of preferred teaching aid/tool

\begin{tabular}{|c|c|c|c|c|c|}
\hline \multicolumn{2}{|c|}{ Response } & Frequency & $\%$ & Valid \% & Cumulative $\%$ \\
\hline \multicolumn{6}{|c|}{ Power Point Slides } \\
\hline \multirow[t]{3}{*}{ Valid } & 1 Yes & 147 & 38.5 & 62.0 & 62.0 \\
\hline & $2 \mathrm{No}$ & 90 & 23.6 & 38.0 & 100.0 \\
\hline & Total & 237 & 62.0 & 100.0 & \\
\hline \multicolumn{2}{|c|}{ No Response } & 145 & 38.0 & & \\
\hline \multicolumn{2}{|c|}{ Total } & 382 & 100.0 & & \\
\hline \multicolumn{6}{|c|}{ Use of interactive notes } \\
\hline \multirow[t]{3}{*}{ Valid } & 1 Yes & 255 & 66.8 & 93.8 & 93.8 \\
\hline & $2 \mathrm{No}$ & 17 & 4.5 & 6.3 & 100.0 \\
\hline & Total & 272 & 71.2 & 100.0 & \\
\hline \multicolumn{2}{|c|}{ No Response } & 110 & 28.8 & & \\
\hline \multicolumn{2}{|l|}{ Total } & 382 & 100.0 & & \\
\hline
\end{tabular}




\begin{tabular}{|c|c|c|c|c|c|}
\hline \multicolumn{2}{|c|}{ Response } & Frequency & $\%$ & Valid \% & Cumulative \% \\
\hline \multicolumn{6}{|c|}{ Spoke and Wrote } \\
\hline \multirow[t]{3}{*}{ Valid } & 1 Yes & 218 & 57.1 & 84.5 & 84.5 \\
\hline & 2 No & 40 & 10.5 & 15.5 & 100.0 \\
\hline & Total & 258 & 67.5 & 100.0 & \\
\hline \multicolumn{2}{|c|}{ No Response } & 124 & 32.5 & & \\
\hline \multicolumn{2}{|l|}{ Total } & 382 & 100.0 & & \\
\hline \multicolumn{6}{|c|}{ Spoke without any visual aids } \\
\hline \multirow[t]{3}{*}{ Valid } & 1 Yes & 32 & 8.4 & 14.4 & 14.4 \\
\hline & 2 No & 190 & 49.7 & 85.6 & 100.0 \\
\hline & Total & 222 & 58.1 & 100.0 & \\
\hline \multicolumn{2}{|c|}{ No Response } & 160 & 41.9 & & \\
\hline \multicolumn{2}{|l|}{ Total } & 382 & 100.0 & & \\
\hline \multicolumn{6}{|c|}{ Social Media } \\
\hline \multirow[t]{3}{*}{ Valid } & 1 Yes & 56 & 14.7 & 27.2 & 27.2 \\
\hline & $2 \mathrm{No}$ & 150 & 39.3 & 72.8 & 100.0 \\
\hline & Total & 206 & 53.9 & 100.0 & \\
\hline \multicolumn{2}{|c|}{ No Response } & 176 & 46.1 & & \\
\hline \multicolumn{2}{|l|}{ Total } & 382 & 100.0 & & \\
\hline
\end{tabular}

Furthermore, standard multiple regression analysis was used to determine the causal relationship between students' academic performance and the different teaching tools to confirm correlations between these variables. The regression results indicate that some of the variation of the different teaching tools is influenced by the perceived context. The result of the model explains the R squared value of 5.9 per cent of the variance in the students' final marks. Of these different teaching tools (See Table 4) only "Interactive notes" was statistically significant and contributed the largest to students' final marks in recording the highest beta value $=-.136, \mathrm{p}=.062$ comparing to the other teaching tools. This finding confirmed that "Interactive notes" is the preferred teaching tool to increase students' academic performance. On the basis of the data collected "interactive notes" as the preferred learning tool is a more effective means of learning in lectures than the other learning tools. Multiple tools were reviewed and concluded that "interactive notes" is now a supported learning tool to improve students' academic performance and learning in lectures. Thus, it is also possible that "interactive notes" is a shift from traditionally teaching, that is more passive, to active learning in engaging with students in lectures especially in large classes that might increase students' academic performance. Furthermore, the presence of the lecturers might have an influence on students' perceptions of learning to engage, interact, participate and raise their opinions in lectures than learning at home. The results of the data collected support this finding. 
Table 4: Coefficients for regression: Students' academic performance and teaching tools

\begin{tabular}{|c|c|c|c|c|c|c|}
\hline \multicolumn{7}{|c|}{ Coefficients $^{a}$} \\
\hline & \multirow{2}{*}{ Model } & \multicolumn{2}{|c|}{ Unstandardized Coefficients } & \multirow{2}{*}{$\begin{array}{c}\begin{array}{c}\text { Standardized } \\
\text { Coefficients }\end{array} \\
\text { Beta }\end{array}$} & \multirow{2}{*}{$\mathbf{t}$} & \multirow{2}{*}{ Sig. } \\
\hline & & B & Std. Error & & & \\
\hline \multirow[t]{6}{*}{1} & (Constant) & 59.227 & 8.719 & & 6.793 & 0.000 \\
\hline & PP Slides & 3.231 & 1.947 & 0.121 & 1.660 & 0.099 \\
\hline & Notes & -6.700 & 3.572 & -0.136 & -1.876 & 0.062 \\
\hline & Spoke and Wrote & -1.446 & 2.460 & -0.043 & -0.588 & 0.557 \\
\hline & Spoke with no visuals & 4.953 & 2.697 & 0.130 & 1.836 & 0.068 \\
\hline & Social Media & -1.338 & 2.093 & -0.046 & -0.639 & 0.523 \\
\hline
\end{tabular}

a. Dependent Variable: Final Mark

In addition, the Normal Probability Plot (P-P) (See Figure 3) all points on the graph are plotted in a reasonably straight line, meaning no major deviations were noted from normality.

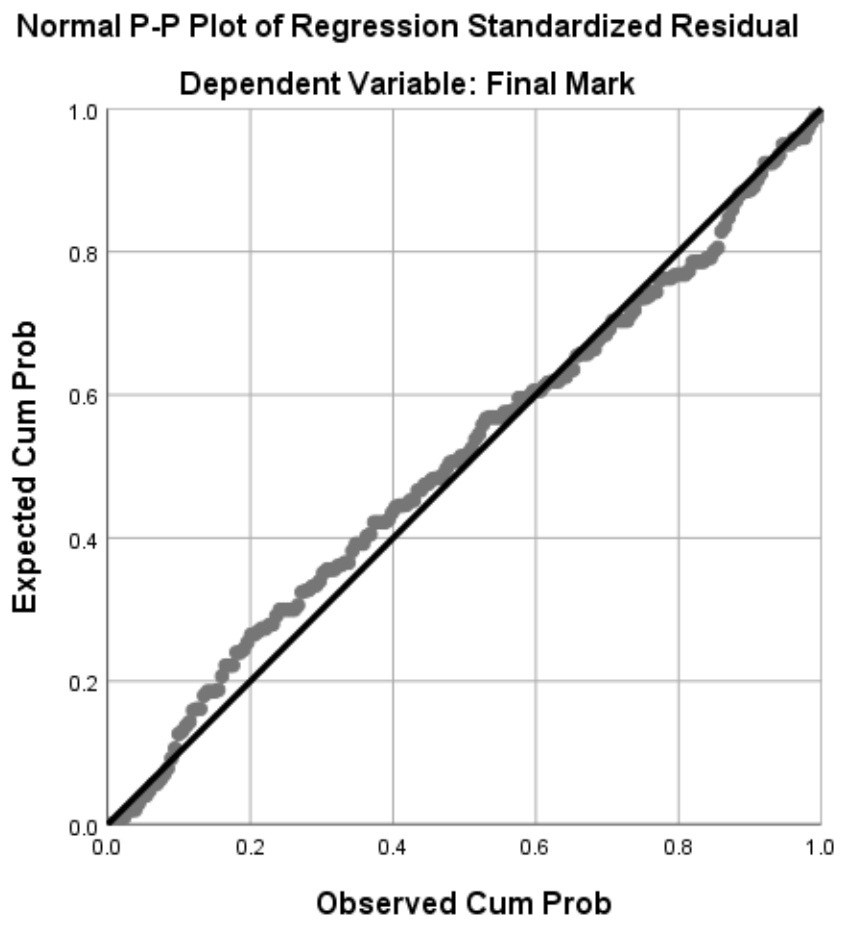

Figure 3: Normal Probability Plot: Final Mark versus Teaching tools

The different teaching aids/tools were compared with gender, race, English as home or additional language, and academic performance of each student. The relationships between the different variables were investigated to determine whether two categorical variables were associated. Preliminary analyses were performed to ensure no violation of the assumptions of normality, linearity and homoscedasticity. The "Pearson Chi-Square" value indicated a significant relation between the teaching tool "Use of interactive notes ..." and academic performance, namely $\chi^{2}(1, \mathrm{n}=382)=17.593, \mathrm{p}=.000$, and also "Spoke and wrote" and 
students' academic performance, with an association of $\chi^{2}(1, n=382)=12.092, p=.001$. No associations were found between the other different teaching aids/tools and students' academic performance as per Table 5. A significant association between the teaching tool "PP slides" and race, namely $\chi^{2}(1, n=382)=15.922, p=.003$ were found. The findings of Biggs (2003) were confirmed by the results of this study that knowledge is created through students' "learning activities" and learning by "filling in the answers" on notes. The level of statistical significance indicates that an association was found between the teaching aid/tool, "Spoke with no visuals notes..." and gender, namely $\chi^{2}(1, n=382)=4.004, p=.045$. A significant association was found between the teaching aid/tool, "interactive notes" and English, namely $\chi^{2}(1, n=382)=$ $5.173, \mathrm{p}=.023$. As the results indicated students who preferred using "interactive notes" are more receptible to students that had English as a HL than students that had English as an FAL. This finding might confirm how "interactive notes" might assist students in bridging the potential barriers presented by language. "Interactive notes" might provide students the opportunity to interact with the lecture material by writing notes in respect of if students had English as a HL or FAL to learn accounting. However, "in Accounting, students first need to learn terminology, basic concepts and procedures" before application (Hall et al. 2004, 502), therefore students need to write notes to master these concepts. Students who had English as FAL might find writing notes more challenging than students who had English as HL and might not favour "interactive notes" as their preferred learning tool.

No associations were found between the other different teaching aids/tools and other variables, namely, gender, race, and English as HL or FAL (see Table 5). The study by Richardson and King (1991, 370) also concluded "that there are no significant gender differences in student learning approaches" such as those adopted by Biggs (1999).

Table 5: Relationship between the different Teaching aids/tools versus gender, race, English and Academic marks Pass/Fail

\begin{tabular}{|c|c|c|c|c|c|c|c|c|c|c|c|c|}
\hline \multirow[t]{2}{*}{$\begin{array}{l}\text { Teaching } \\
\text { aid/tool }\end{array}$} & \multicolumn{3}{|c|}{ Gender } & \multicolumn{3}{|c|}{ Race } & \multicolumn{3}{|c|}{ English } & \multicolumn{3}{|c|}{$\begin{array}{c}\text { Academic marks } \\
\text { Pass/Fail }\end{array}$} \\
\hline & Values & df & $\begin{array}{l}\text { Asymp. } \\
\text { Sig. (2- } \\
\text { sided) }\end{array}$ & Values & df & $\begin{array}{l}\text { Asymp. } \\
\text { Sig. (2- } \\
\text { sided) }\end{array}$ & Values & df & $\begin{array}{l}\text { Asymp. } \\
\text { Sig. (2- } \\
\text { sided) }\end{array}$ & Values & df & $\begin{array}{l}\text { Asymp. } \\
\text { Sig. (2- } \\
\text { sided) }\end{array}$ \\
\hline PP Slides & $.145^{a}$ & 1 & .704 & $15.922^{\mathrm{a}}$ & 4 & $.003^{\star \star *}$ & $1.436^{\mathrm{a}}$ & 1 & .231 & $.099^{a}$ & 1 & .753 \\
\hline Interactive Notes & $.823^{a}$ & 1 & .364 & $7.853^{a}$ & 4 & $.097^{*}$ & $5.173^{a}$ & 1 & $.023^{* *}$ & $17.593^{a}$ & 1 & $.000^{* * *}$ \\
\hline Spoke and wrote & $.170^{a}$ & 1 & .680 & $5.569^{a}$ & 4 & .234 & $1.300^{\mathrm{a}}$ & 1 & .254 & $12.092^{\mathrm{a}}$ & 1 & $.001^{* * *}$ \\
\hline $\begin{array}{l}\text { Spoke with no } \\
\text { visuals }\end{array}$ & $4.004^{\mathrm{a}}$ & 1 & $.045^{* *}$ & $8.895^{\mathrm{a}}$ & 4 & $.064^{*}$ & $.695^{a}$ & 1 & .404 & $.244^{a}$ & 1 & .621 \\
\hline Social Media & $.768^{a}$ & 1 & .381 & $6.952^{\mathrm{a}}$ & 4 & .138 & $.478^{a}$ & 1 & .489 & $2.277^{a}$ & 1 & .132 \\
\hline
\end{tabular}

a. 0 cells $(.0 \%)$ have expected count less than 5 . The minimum expected count is 19.95 .

All significant values indicate with an ${ }^{*} p<10 \%,{ }^{* *} p<5 \%,{ }^{* * *} p<1 \%$

Students indicated in the open-ended questions several suggestions of how to learn in lectures. 
By addressing the perceptions and opinions of accounting students' responses, the motivation for this study is further justified that flipped lectures, using interactive notes instead of comprehensive notes provides lecturers the opportunity to react to students' responses. This study therefore gained a better understanding of the perceptions and opinions of students of how they learn in lectures in accounting studies.

The findings of the open-ended questions were grouped together and presented in Table 6. The following themes were identified that underpin the theoretical framework of the study; listen, engage, assess, revise by reading and interactive notes (Figure 2). The participants experienced these critical engagements on many different levels of how they perceive and experience learning in lectures. Participants were very enthusiastic about sharing their opinions in answering the open-ended questions that were not compulsory, a response rate of 76 per cent was recorded. The themes and verbatim quotes are illustrated in Table 6.

Table 6: Themes and participants' responses

\begin{tabular}{|c|c|c|}
\hline No & Theme & Participants' verbatim responses \\
\hline 1. & Listen & $\begin{array}{l}\text { "Less lecture slides and more interaction with us students" } \\
\text { "More slides and speak with clarity" } \\
\text { "Slow down their speed when lecturing" } \\
\text { "Sometimes the lecturers are too fast" } \\
\text { "Sometimes they go at a fast pace" }\end{array}$ \\
\hline 2. & Engage & $\begin{array}{l}\text { "Allow all students participation in class lessons" } \\
\text { "By encouraging more interaction between lecturers and students" } \\
\text { "Encourage class participation but don't force it" } \\
\text { "Lectures can be improved by engaging with the students in the lecture" } \\
\text { "Allow more time for questions and examples" } \\
\text { "Increase interaction between learners and lecturers" }\end{array}$ \\
\hline 3. & Assess & $\begin{array}{l}\text { "Better notes and exam type questions" } \\
\text { "Check homework" } \\
\text { "Give solutions to all of the exams" } \\
\text { "More examples so we are not surprised when we see the exam paper" } \\
\text { "Only include examinable material" }\end{array}$ \\
\hline 4. & $\begin{array}{l}\text { Revise by } \\
\text { reading }\end{array}$ & $\begin{array}{l}\text { "Focus on the key areas. Reiterate what has been taught" } \\
\text { "Go over past papers" } \\
\text { "Going over past exam papers" } \\
\text { "Weekly class tests to test knowledge on that week's topic" }\end{array}$ \\
\hline 5. & $\begin{array}{c}\text { Notes, } \\
\text { interactive }\end{array}$ & $\begin{array}{l}\text { "Use notes, not lecture slides" } \\
\text { "By doing interactive examples with students" } \\
\text { "If all lecturers can use notes where we have to fill in answers to short questions to } \\
\text { examples" } \\
\text { "Notes for all the topics should be available for students" } \\
\text { "Lecturers should be more interactive" } \\
\text { "More interaction with students" }\end{array}$ \\
\hline
\end{tabular}

The findings of the research include the identification of five themes from the data collected. 
Firstly, listen, includes that some students prefer lecturers to slow down their lecture pace to allow students to listen, grasp and understand accounting concepts and principles. Secondly, engage, found that participants viewed their learning to allow students to participate in lectures and by engaging in lectures to allow more time for questions and examples. Thirdly, assess, draws on the attention that students prefer to be prepared for tests and examinations by including more examples and notes in lectures. Fourthly, revise by reading, includes the feedback from the participants and records the quest to revise course material and weekly class tests to test their knowledge and accounting concepts. And finally, the last theme, interactive notes, indicates participants' reflections on the way they learn and/or acquire knowledge in lectures. Most of the respondents' views demonstrated that using interactive notes could be beneficial to their approach to learning if all lecturers used notes where they have to fill in answers to short questions and do examples in lectures, than using comprehensive notes.

\section{CONCLUSION}

This article concludes an investigation into lectures at a South African university, recording students' perceptions and their preferences for different teaching aids/tools in these lectures. This study confirms that students learn in different ways, and that their preferences for different teaching aids/tools might reflect their different backgrounds and the expectations they bring to their own learning. The research was conducted among registered Accounting I students; 382 first-year Accounting students responded to a questionnaire.

The following objectives of the study were addressed by the research questions to achieve the purpose of the study; to identify the current teaching aid/tool first year accounting students prefer. This was done to establish whether students prefer a particular teaching aid/tool, and to establish whether there were any relationships between the preferred teaching aid/tool and other variables such as gender, race, language and academic performance.

The first objective confirmed that the "use of interactive notes ..." scored the highest approval rating, with 66.8 per cent, followed by "spoke and wrote on the board and overhead", which scored 57.1 per cent. The "use of interactive notes ..." as the most effective tool when learning accounting indicates that interactive learning is what the students enjoyed the most, which confirms the studies of Hoyle (2006), Bain (2004) and Morton (2009), assisting students to understand the content more effectively. The completing of the interactive notes in lectures could therefore allow lecturers to engage more with the students and create a learning environment; this concurs with Hoyle (2006) and Bain (2004). The findings of Biggs (2003) also concur with the findings of this study. A number of students indicated that lectures could be improved through "interaction and participation". Due to the large Accounting I class, an 
attempt to achieve this was provided through "the use of interactive notes ...", but clearly students need more interaction and participation in lectures. The "strengths and weaknesses of students are extremely important, no matter how motivated a student might be, the inability to absorb and retain information in lectures can dampen their motivation and prevent achievement" (Boyle and Dunn 1998, 222; Dunn and Dunn 1979, 244). In addition, students obtained higher Accounting I marks when they had English as a HL in relation to students who had English as a FAL. Jacobs (2000) suggests that lecturers need to recognise these diverse backgrounds, as some students need assistance with the adaptation from school to higher education.

The second objective was to determine students' perceptions and opinions of how they learn in lectures. This was motivated by the desire to determine what lecturers could do differently to enhance the lecture experience and assist students with their understanding of the course material. Respondents responded as follows, indicating the lecturer (Lecturer X) that used "interactive notes" in lectures: "Other lecturers could use the notes the same way Lecturer X did", "If other lecturers could implement Lecturer's X kind of notes" and "Lecturers can help us solve problems, and not only feed us with information. Lecturer X does this nicely". Students also responded that the other lecturers who do not used "interactive notes" as follow: "Lecturer Y, he should use notes as other lecturers", "If all lecturers can use notes where we have to fill in answers to short questions" and "Lecturers should be more interactive". After the survey was analysed, the course lecturers re-structured the course to include "interactive notes" in lectures to be used by all the course lecturers since "interactive notes" might contribute to increasing students' academic performance as one of many factors that could affect the academic performance of students.

The third objective determined the association between the use of "interactive notes" and the performance of students. One of the students responded as follows: "Lecturer X should always teach, I do much better in her sections" indicating that Lecturer X used "interactive notes" and students' academic performance is higher in those sections lectured by Lecturer X, than other lecturers that did not use "interactive notes". This study found that there is an association between the teaching aid/tool, the "use of interactive notes ...", and students' academic performance. The regression results indicate that "interactive notes" was the only teaching tool that was statistically significant and made the largest contribution to students' final mark comparing to the other teaching tools. This finding confirmed that "interactive notes" is the preferred teaching tool to increase students' academic performance. This finding supports the achieving approach that was introduced by Biggs (1987), which is associated with assessment where the emphasis is for students to obtain a high academic performance. 
These suggestions and improvements add value to the study since the main purpose of teaching should be to encourage and promote learning, providing lecturers the opportunity for a better understanding of and greater sensitivity to their students' learning that could influence students' academic performance. Large universities continue to have large classes, especially in first year and knowing that "interactive notes" could make a positive difference contributing to learning could be a way to improve lectures and performance outcome. Furthermore, the research findings contribute to Accounting teaching and learning in Higher Education that “accounting lecturers can influence students' learning by using 'interactive notes' by adopting specific changes in the learning environment" (Part two of Figure 1) that might increase students' academic performance (Part five of Figure 1) (Hall et al. 2004, 502). In order to achieve these goals, higher education institutions need to examine the association between interactive learning in lectures, and students' academic performance, and to encourage other lecturers to incorporate different teaching aids/tools in their lectures to complement students' learning characteristics and assist them to obtain better academic marks. Such a change may assist students to learn in lectures and linking learning to active engagement in lectures (Cano 2005; Rodriguez and Cano 2006).

\section{LIMITATIONS AND FUTURE RESEARCH}

Limitations include a single university, only accounting students in their first-year of study and a longitudinal study which could track whether the use of different teaching aids/tools might have an impact on the academic marks of students. The results of this study should be shared with other lecturers in the university, as well as at other universities, in order to allow them to reflect on their own teaching practices. Future research could be extended to include more than one academic year. In addition, it is further recommended that lecturers need to investigate prior research regarding new and innovative ways of using different teaching aids/tools to increase students' academic performance. Lecturers should therefore be encouraged to adopt this strategy in identifying teaching and learning tools that could assist students to learn in lectures, thereby assisting students to pass and eventually graduate.

\section{REFERENCES}

Albrecht, W. S. and R. J. Sack. 2000. "Accounting Education: Charting the Course through a Perilous Future." Accounting Education Series, Vol. 16. Sarasota, Fl.: American Accounting Association.

Apfelthaler, G., K. Hansen, S. Keuchel, M. Neubauer, S. H. Ong, N. Tapachai, and C. Mueller. 2005. "Cross-cultural Learning Styles in Higher Education." International Journal of Learning 12: 24756.

Asikainen, H. and D. Gijbels. 2017. “Do Students Develop Towards More Deep Approaches to Learning 
During Studies? A Systematic Review on the Development of Students' Deep and Surface Approaches to Learning in Higher Education." Educational Psychology Review 29(2): 205-234.

Bain, K. 2004. What the best college teachers do. New York, NY: Harvard Press.

Bartlett, S., M. J. Peel, and M. Pendlebury. 1993. "From fresher to finalist: A three-year analysis of student performance on an accounting degree programme." Accounting Education: An International Journa1 2: 111-122.

Bergin, J. L. 2001. "The effect of previous accounting study on student performance in the first collegelevel financial accounting course". Issues in Accounting Education: 19-28.

Beyleveld, M., J. J. R. De Villiers, and W. J. Fraser. 2019. "The use of active learning in a private higher education institution: The lecturer's perspective." South African Journal of Higher Education 33(2): 16-28.

Biggs, J. B. 1985. "The role of metalearning in study processes." British Journal of Educational Psychology 55: 185-212.

Biggs, J. B. 1987. Student approaches to learning and studying. Camberwell, Victoria: Australian Council for Educational Research.

Biggs, J. B. 1993. "What do inventories of students' learning process really measure? A theoretical review and clarification." British Journal of Educational Psychology 63: 3-19.

Biggs, J. B. 1999. "What the Student Does: Teaching for enhanced learning." Higher Education Research and Development 18: 57-75.

Biggs, J. B. 2003. Teaching for Quality Learning at University. ${ }^{\text {nd }}$ Edition. Milton Keynes: The Society for Research into Higher Education.

Biggs, J., D. Kember, and D. Y. P. Leung. 2001. “The Revised Two Factor Study Process Questionnaire: R-SPQ-2F.” British Journal of Educational Psychology 71: 133-149.

Bristol, T. J. 2014. Flipping the classroom. Teaching and Learning in Nursing 9: 43-46.

Bishop, J. L., and M. A. Verleger. 2013. The Flipped Classroom: Survey of the Research. $120^{\text {th }}$ ASEE Annual Conference and Exposition. American Society for Engineering Education, Atlanta.

Booth, P., P. Luckett, and R. Mladenovic. 1999. "The quality of learning in accounting education: The impact of approaches to learning on academic performance." Accounting Education: An International Journal 8: 277-300.

Boyle, R., and R. Dunn. 1998. "Teaching law students through individual learning styles." Albany Law Review 62: 213-247.

Cano, F. 2005. "Epistemological beliefs and approaches to learning: their change through secondary school and their influence on academic performance." British Journal of Educational Psychology 75: 203-221.

Chansarkar, B. A. and A. Michaeloudis. 2001. "Student Profiles and factors affecting performance." International Journal of Mathematics Education in Science Technology 32: 97-104.

Dennehy, E. 2014a. "Learning approaches and cultural influences: A comparative study of Confucian and western-heritage students." Journal of Further and Higher Education. http://dx.doi.org/ 10.1080/0309877X.2013.869561.

Dennehy, E. 2014b. "Is deep learning rewarded? A quantitative study on the relationship between learning approaches and academic scores." International Journal of Teaching and Case Studies 5: 54-68.

De Vita, G. 2010. "Learning Styles, Culture and Inclusive Instruction in the Multicultural Classroom: A Business and Management Perspective." Innovations in Education and Teaching International 38: $165-174$.

Dockweiler, R. C. and C. G. Willis. 1984. "On the use of entry requirements for undergraduate accounting programs." The Accounting Review 59(3): 496-504.

Duff, A. 2007. "Understanding academic performance and progression of first-year accounting and 
business economics undergraduates: The role of approaches to learning and pro academic achievement." Accounting Education 13: 409-430.

Dunn, R. S. and K. J. Dunn. 1979. "Learning styles/Teaching Styles: Should they? Can they? Be Matched?" Educational Leadership: 238-244.

Fry, H., S. Ketteridge, and S. Marshall. 2009. A handbook for teaching and learning in higher education. $3^{\text {rd }}$ Edition. New York, NY: Routledge.

Gammie, E., B. Paver, B. Gammie, and F. Duncan. 2010. "Gender differences in accounting education: An undergraduate exploration." Accounting Education 12: 177-196.

Gul, F. A. and S. C. C. Fong. 1993. "Predicting factors for introductory accounting students: Some further Hong Kong evidence." Accounting Education 2: 33-42.

Hall, M., A. Ramsey, and J. Raven. 2004. "Changing the learning environment to promote deep learning approaches in first-year accounting students." Accounting Education 13(4): 489-505.

Hoyle, J. B. 2006. Tips and thoughts on improving the teaching process in college. Richmond: Hoyle.

Jacobs, D. 2000. "A Chemical Mixture of Methods." In From Opening Lines: Approaches for the Scholarship of Teaching and Learning, ed. P. Hutchings. Princeton, NJ: Carnegie Foundation for the Advancement of Teaching.

Jensen, J. L., T. J. Kummer, and P. Godoy. 2015. "Improvements from a Flipped Classroom May Simply Be the Fruits of Active Learning." Life Sciences Education 14: 1-12.

Johnson, L. A. 2003. A toolbox for humanity. Trafford: Victoria.

Kember, D., and L. Gow. 1994. "Orientations to teaching and their effect on the quality of student learning." Journal of Higher Education 65(1): 58-74.

Kember, D., Q. W. Jamieson, M. Pomfret, and E. T. Wong. 1995. "Learning approaches, study time and academic approaches." Higher Education 29: 329-343.

Kim, J-Y. 2017. "A study of students' perspectives on a flipped learning model and associations among personality, learning styles and satisfaction." Innovations in Education and Teaching International 1. Online.

Koh, M. Y. and H. C. Koh. 1999. "The determinants of performance in an accountancy degree Programme." Accounting Education: An International Journal 8: 13-29.

Koo, C. I., E. L. Demps, C. Farris, J. D. Bowman, L. Panahi, and P. Boyle. 2016. "Impact of Flipped Classroom Design on Student Performance and Perceptions in a Pharmacotherapy Course." American Journal of Pharmaceutical Education 80: 2, Article 33.

Love, B., A. Hodge, N. Grandgenett, and A. W. Swift. 2014. "Student learning and perceptions in a flipped linear algebra course." International Journal of Mathematical Education in Science and Technology 45: 317-324.

Lucas, L. and J. H. F. Meyer. 2005. “"Towards a mapping of the student world': The identification of variation in students' conceptions of, and motivations to learn, introductory accounting." The British Accounting Review 37: 177-204.

Malmquist, S. J. and W. F. Collins. 2017. "Interactions Between Student Attitudes, Affect and Outcomes During a Transition to an Active Learning Format in Introductory Physiology." The Official Journal of the Federation of American Societies for Experimental Biology 37(1): No 1 Supplement 576.2.

Marburger, D. R. 2010. "Does Mandatory Attendance Improve Student Performance?” The Journal of Economic Education 37: 148-155.

Marton, F. and S. Booth. 1997. Learning and Awareness. Mahwah, NJ: Lawrence Erlbaum Associates.

Mashishi, K. and E. Rabin. 2000. "A study of the approaches to learning, engagement with the learning context and conceptions of learning of a group of fourth year accounting students." South African Journal of Accounting Research 14: 1-19.

Morton, A. 2009. A handbook for teaching and learning in higher education: Lecturing large groups, 
ed. H. Fry, S. Ketteridge, and S. Marshall. $3^{\text {rd }}$ Edition. New York, NY: Routledge.

Müller, H., P. Prinsloo, and A. Du Plessis. 2007. "Validating the profile of successful first-year accounting students." Meditari Accounting Research 15: 19-33.

Papageorgiou, E. and C. W. Callaghan. 2018. "Parental style and gendered student performance in the South African context of accounting studies." Accounting Education 27(5): 456-478.

Papageorgiou, E. 2017. “Accounting students' profile versus academic performance: A five-year analysis." South African Journal of Higher Education 31(3): 209-229.

Pierce, R., J. Fox, and B. J. Dunn. 2012. "Vodcasts and Active-Learning Exercises in a "Flipped Classroom' Model of a Renal Pharmacotherapy Module." American Journal of Pharmaceutical Education 76: 1-5.

Pratt, D. 2005. "Personal Philosophies of Teaching: A False Promise." http://www.jstor.org/action/ showPublication?journalCode $=$ academe.

Precourt, E. and M. Gainor. 2019. "Factors affecting classroom participation and how participation leads to a better learning." Accounting Education 28(1): 100-118.

Raaheim, K., J. Wankowski, and J. Radford. 1991. Helping students to learn at university. Milton Keynes: The Society for research into Higher Education, Open University Press.

Ramsden, P. 1992. Learning to Teach in Higher Education. London: Routledge.

Richardson, J. T. E. and E. King. 1991. "Gender Differences in the Experience of Higher Education: Quantitative and qualitative approaches in Educational Psychology." International Journal of Experimental Educational Psychology 11: 362-382.

Roach, T. 2014. "Student perceptions toward flipped learning: New methods to increase interaction and active learning in economics." International Review of Economics Education 17: 74-84.

Rodríguez, L. and F. Cano. 2006. "The epistemological beliefs, learning approaches and study orchestrations of university students." Studies in Higher Education 31(5): 617-636.

Rotellar, C. and J. Cain. 2016. "Research, Perspectives, and Recommendations on Implementing the Flipped Classroom.” American Journal of Pharmaceutical Education 80(2) Article 34: 1-9.

Rowlands, J. E. 1988. "The effect of secondary school accounting study on university accounting performance." De Ratione 2: 17-21.

Sharma, D. S. 1997. “Accounting students' learning conceptions approaches to learning, and the influence of the learning-teaching context on approaches to learning." Accounting Education 6(2): $125-146$.

Sikka, P., C. Haslam, O. Kyriacou, and D. Agrizzi. 2007. "Professionalizing Claims and the State of UK Professional Accounting Education: Some Evidence." Accounting Education: International Journal 16: 3-21. https://www.tandfonline.com/doi/full/10.1080/09639280601150921.

Scott, I., N. Yeld, and J. Hendry. 2007. "A case for improving teaching and learning in South African higher education." Higher Education Monitor No. 6. Pretoria: Council on Higher Education.

Scrivener, J. 2005. Learning Teaching. Oxford: Macmillan.

Steenkamp, L. P., R. S. Baard, and B. L. Frick. 2009. "Factors Influencing Success in First-Year Accounting at a South African University: A Comparison between Lecturers' Assumptions and Students' Perceptions." South African Journal of Accounting Research 23(1): 113-140. https://doi.org/10.1080/10291954.2009.11435142.

Stone, B. B. 2012. Flip your classroom to increase interactive learning and student engagement. 28th Conference in Distance Teaching and Learning, Madison, Wisc.

Strayer, J. F. 2012. "How learning in an inverted classroom influences cooperation, innovation and task orientation." Learn Environment 15: 171-193.

Tait, H. and N. J. Entwistle. 1996. "Identifying students at risk through ineffective study strategies." Higher Education 31: 97-116.

Van Rensburg, P., G. Penn, and M. Haiden. 1998. "A note on the effect of secondary school accounting 
study on university accounting performance." South African Journal of Accounting Research 12: 93-98.

Venter, A. 2019. "Social Media and social capital in online learning." South African Journal of Higher Education 33(3): 241-257.

Visser, S., S. McChlery, and N. Vreken. 2006. "Teaching styles versus learning styles in the accounting sciences in the United Kingdom and South Africa: A comparative analysis." Meditari Accounting Research 14: 97-112.

Winebrenner, S. 2007. Teaching Kids with learning difficulties in the regular classroom. Golden Valley, $\mathrm{MN}$ : Free Spirit Publishing.

Wong, D. S. N. and Y. Chia. 1996. "English language, mathematics and first year financial accounting performance: A research note." Accounting Education 5: 183-189.

Zhang, D. 2005. Action Research on Large Class Activity. http://users.monash.edu.au/ dengs/ teaching/GCHE/Action\%20Research\%20on\%20Large\%20Class\%20Activity.pdf. 